\title{
ANALISIS DEBIT BANJIR SUNGAI CIJANGKELOK DI DESA CIBINGBIN KECAMATAN CIBINGBIN KABUPATEN KUNINGAN
}

\author{
Nono Carsono \\ Sekolah Tinggi Teknologi Cirebon \\ Email: nonocrs74@gmail.com
}

\section{Abstract}

The research method used in this research is descriptive quantitative method. Quantitative research, as the name implies, is required to use numbers, starting from data collection, interpretation of the data, and its appearance and results. Likewise, an understanding of research conclusions accompanied by tables, graphs, charts, pictures or other views. Hydrology analysis on Cijangkelok River was carried out with frequency analysis starting from the calculation of regional rainfall using the Polygon Thiessen method so that the statistical parameter prices for the calculation of design rain were carried out on the maximum annual daily rainfall data for 15 years (2005 to 2019) with a return period of 2 years, 5 years, 10 years, 25 years, 50 years, and 100 years. The results of the rainfall calculation for the 5 year return period design of the Gumbel distribution are 136,76 mm and the results of the Log Pearson Type III distribution are 127,83 mm. From the results of the frequency analysis of the distribution types that meet the requirements, namely the Log Pearson Type III distribution with a value of $C s=$ 0,753 then from the results of the Smirnov-Kolmogorov harmony test with a significance degree of $5 \%$ and a value of $\Delta$ maks $<\Delta c r=0,134<0,338$., Then the Log Pearson Type III method can be used to calculate rainfall for a certain return period. The flood discharge design for the 5 year return period of the Synthetic Unit Hydrograph (HSS) Nakayasu method is 742,248 m3/s with an hourly rainfall intensity of the Mononobe method with a duration of 4 hours of 17,587 mm/hour. With the river capacity obtained from the results of discharge calculations using the mid section method $239.30 \mathrm{m3} / \mathrm{s}$, it can be concluded that the Cijangkelok River cannot accommodate and has the potential for flooding, and there is a need for normalization or elevation of water structures and or embankments on the Cijangkelok River.

Keywords: $\quad$ flood design; Synthetic Unit Hydrograph (SUH) nakayasu; design rainfall; return period
Abstrak
Penelitian ini bertujuan untuk menganalisis data hidrologi dan menganalisis debit banjir rencana pada Sungai Cijangkelok di Desa Cibingbin Kecamatan Cibingbin Kabupaten Kuningan. Metode Penelitian yang digunakan dalam penelitian ini adalah metode kuantitatif deskriftif. Penelitian kuantitatif sesuai dengan namanya banyak dituntut menggunakan angka, mulai dari pengumpulan data, penafsiran

$\begin{array}{ll}\text { How to cite: } & \text { Carsono, Nono dan Alfianudin Ahmad (2021) Analisis Debit Banjir Sungai Cijangkelok Di Desa } \\ & \text { Cibingbin Kecamatan Cibingbin Kabupaten Kuningan. Syntax Literate: Jurnal Ilmiah Indonesia 6(4). } \\ & \text { http:// } 10.36418 / \text { syntax-literate.v6i4.2469 } \\ & 2548-1398 \\ \text { E-ISSN: } & \text { Ridwan Institute }\end{array}$


terhadap data tersebut, serta penampilan dan hasilnya. Demikian juga pemahaman akan kesimpulan penelitian disertai tabel, grafik, bagan, gambar atau tampilan lain. Analisis Hidrologi pada Sungai Cijangkelok dilakukan dengan analisis frekuensi mulai dari perhitungan curah hujan wilayah cara Poligon Thiessen sehingga diperoleh harga parameter statistik untuk perhitungan hujan rancangan yang dilakukan terhadap data curah hujan harian maksimum tahunan selama 15 tahun (tahun 2005 s.d. tahun 2019) dengan kala ulang 2 tahun, 5 tahun, 10 tahun, 25 tahun, 50 tahun, dan 100 tahun. Hasil perhitungan curah hujan rancangan kala ulang 5 tahun distribusi Gumbel sebesar 136,76 $\mathrm{mm}$ dan hasil distribusi Log Pearson Type III sebesar 127,83 mm. Dari hasil analisa frekuensi jenis distribusi yang memenuhi syarat yaitu distribusi Log Pearson Type III dengan nilai Cs = 0,753 selanjutnya dari hasil Uji keselarasan Smirnov-Kolmogorov dengan derajat signifikasi $5 \%$ dan nilai $\Delta$ maks $<\Delta \mathrm{cr}=0,134<0,338$., maka Metode Log Pearson Type III dapat digunakan untuk menghitung curah hujan periode ulang tertentu. Debit banjir rancangan kala ulang 5 tahun Metode Hidrograf Satuan Sintetik (HSS) Nakayasu sebesar 742,248 m3/det dengan intensitas curah hujan jam jaman metode Mononobe durasi 4 jam sebesar 17,587 mm/jam. Dengan kapasitas sungai yang didapat dari hasil perhitungan debit menggunakan metode mid section 239,30 m3/dt maka dapat disimpulkan bahwa Sungai Cijangkelok sudah tidak dapat menampung dan berpotensi banjir, dan perlu adanya normalisasi atau peninggian bangunan air dan atau tanggul pada Sungai Cijangkelok.

Kata kunci: debit banjir rancangan; Hidrograf Satuan Sintetik (HSS) nakayasu; hujan rancangan; kala ulang.

\section{Pendahuluan}

Curah hujan yang tinggi mengakibatkan debit air sungai menjadi lebih besar. Debit air sungai yang besar tidak mampu dialirkan oleh alur sungai, atau debit air sungai lebih besar dari kapasitas alur sungai yang ada, sehingga menyebabkan banjir (Neno, Harijanto, \& Wahid, 2016). Selain itu kurangnya kesadaran masyarakat yang membuang limbah/sampah ke sungai yang tentunya akan berpotensi meningkatkan banjir. Di Sungai Cijangkelok Desa Cibingbin saat ini pada badan sungai terdapat endapan sedimen akibat erosi/gerusan pada tanggul sungai oleh banjir yang mengakibatkan pendangkalan alur serta penyempitan penampang sungai, sehingga sungai tidak mampu lagi menampung debit air yang mengalir. Lokasi penelitian berada di Sungai Cijangkelok Desa Cibingbin Kecamatan Cibingbin Kabupaten Kuningan pada Daerah Aliran Sungai (DAS) Cisanggarung. 


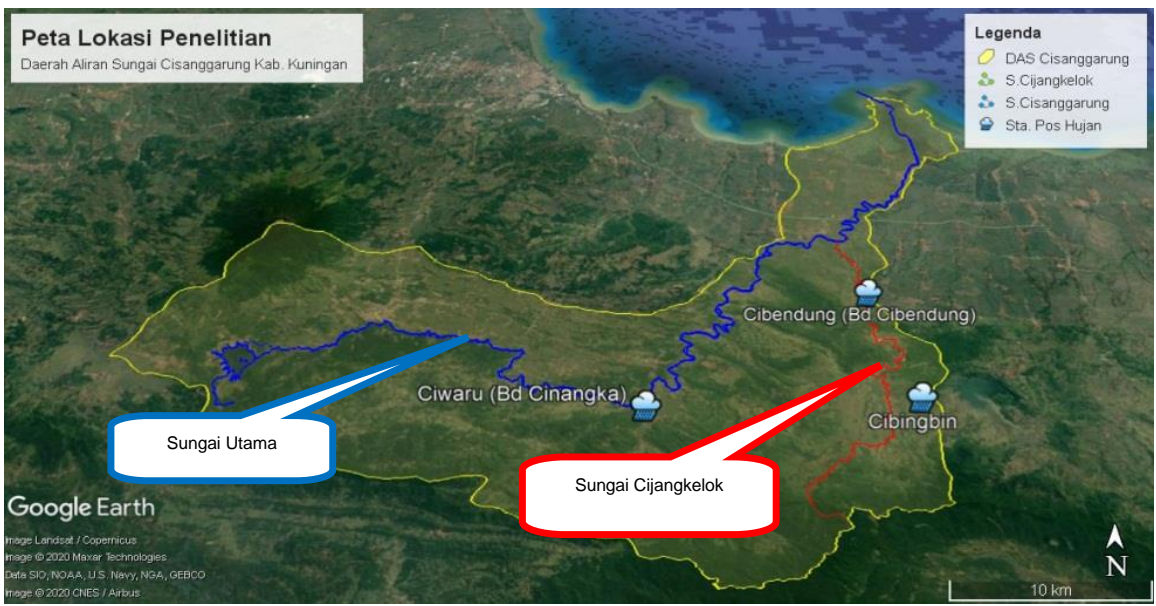

Gambar 1 Lokasi Kajian Penelitian

Sumber: BBWS Cimanuk-Cisanggarung; Google Earth 2020

Daerah Aliran Sungai (DAS) suatu daerah tertentu yang bentuk dan sifat alamnya sedemikian rupa, sehingga merupakan satu kesatuan dengan sungai dan anak-anak sungai yang melalui daerah tersebut dalam fungsinya untuk menampung air yang berasal dari air hujan dan sumber-sumber air lainnya yang penyimpanannya serta pengalirannya dihimpun dan ditata berdasarkan hukum-hukum alam sekelilingnya demi keseimbangan daerah tersebut (Kodoatie, 2018). Sungai adalah alur atau wadah air alami dan/ atau buatan berupa jaringan pengairan air beserta air di dalamnya, mulai dari hulu sampai muara, dengan dibatasi kanan dan kiri oleh garis sempadan (Peraturan Menteri PUPR No. 28 tahun 2015) (Manurung, 2017).

Banjir adalah peristiwa meluapnya air sungai melebihi palung sungai. Banjir bandang adalah banjir besar yang terjadi secara tiba-tiba karena meluapnya debit yang melebihi kapasitas aliran alur sungai oleh konsentrasi cepat hujan dengan intensitas tinggi serta sering membawa aliran debris bersamanya atau runtuhnya bendung alam, yang terbentuk dari material longsoran gelincir pada area hulu sungai (Badan Pengembangan Infrastruktur Wilayah Kementerian PUPR, 2016).

Penyebab banjir yang paling dominan adalah alih fungsi lahan yang sebelumnya merupakan ruang terbuka hijau atau kawasan hutan berubah menjadi ruang terbangun terutama perumahan seiring dengan penduduk yang terus tumbuh (Oktarian, 2016). Upaya-upaya pemerintah dalam pengendalian banjir terutama dengan metode struktur akan kalah cepat dengan tingkat kerusakan DAS akibat perubahan tata guna lahan yang konsekuensinya banjir makin bertambah walau sudah dibangun infrastruktur keairan dengan biaya yang sangat mahal. Bisa diibaratkan secara matematis pengendalian banjir bersifat deret hitung namun bencana banjir bersifat deret ukur (Kodoatie, 2018).

\section{A. Konsep Perhitungan}

Konsep perhitungan didasarkan pada data yang ada, hasil kajian studi literatur dengan menyesuaikan kondisi lapangan di Sungai Cijangkelok. Adapun langkahlangkah sebelum dilakukan perhitungan debit banjir adalah: 
a. Analisis Hidrologi

1) Analisis Curah Hujan Rancangan

Untuk menganalisa hujan rata-rata daerah pengaliran diperlukan Peta Daerah Aliran Sungai (DAS) (Limantara, 2010). Ada 3 (tiga) cara yang biasa dipakai untuk menentukan besarnya curah hujan daerah (area rainfall), yaitu sebagai berikut:

1. Rata-rata Hitung

2. Poligon Thiessen

3. Isohyet

Analisis curah hujan dilakukan dengan maksud untuk menentukan Curah hujan lebih (excess rainfall) dipakai untuk menghitung debit (banjir) (Triwibowo, 2021). Data curah hujan harian yang meliputi periode sedikitnya 10 tahun akan diperlukan.

2) Parameter Statistik

Parameter statistik yang digunakan dalam perhitungan analisis frekuensi meliputi:

1. Nilai rata-rata $(\bar{x})$,

2. Simpangan baku $(S d)$,

3. Koefisien Variasi $(C v)$,

4. Koefisien Kemiringan $(C s)$, dan

5. Koefisien Kurtosis $(C k)$

3) Analisis Frekuensi

Analisis frekuensi ini dapat dilakukan dengan menggunakan distribusi kemungkinan teori probability distribution antara lain Distribusi Gumbel, Distribusi Log Pearson Type III, Distribusi Normal, Distribusi Hazen dan lain-lain (Lalu Budi, 2020).

4) Testing of Goodness of Fit

1. Uji Smirnov-Kolmogorov

Uji Smirnov-Kolmogorov sering juga disebut sebagai uji kecocokan non-parametric, karena pengujiannya tidak memakai fungsi distribusi tertentu. Pengujian dilakukan dengan membandingkan probabilitas tiap data, antara sebaran empiris dan sebaran teoritis, yang dinyatakan dalam $\Delta$. Harga $\Delta$ terbesar ( $\Delta$ maks) dibandingkan dengan $\Delta$ kritis (dari Tabel Smirnov Kolmogorov) dengan tingkat keyakinan $(\alpha)$ tertentu. Distribusi dianggap sesuai jika : $\Delta$ maks $<\Delta$ kritis (Limantara, 2010).

\section{b. Analisis Debit Sungai}

Debit (Q) merupakan jumlah zat cair yang mengalir melalui suatu penampang melintang per satuan waktu, dinyatakan dalam satuan $\mathrm{m}^{3} / \mathrm{s}$, liter/s, liter/menit, dan seterusnya (Suripin, 2019).

Secara matematis dapat dirumuskan secara sederhana menjadi: 
$\mathrm{Q}=\mathrm{A} * \mathrm{~V}$

Dimana :

$\mathrm{Q}=\operatorname{Debit}\left(\mathrm{m}^{3} / \mathrm{s}\right)$

A $=$ Luas Penampang Melintang $\left(\mathrm{m}^{2}\right)$

$\mathrm{V}=$ Kecepatan Arus $(\mathrm{m} / \mathrm{s})$

Terdapat 2 (dua) jenis data yang secara umum dapat dipakai untuk menentukan banjir rancangan antara lain data debit dan data hujan. Masingmasing data yang digunakan mempunyai kekhususan atau spesifikasi, baik yang berkenaan dengan input, output, maupun proses yang dipakai (Limantara, 2010).

Langkah-langkah dalam perhitungan debit banjir dengan cara Unit Hidrograf adalah:

1. Distribusi Hujan Jam-Jaman

a) Mononobe

Rumus Mononobe merupakan sebuah variasi dari rumus jenis Talbot, Sherman, dan Ishiguro adalah rumus-rumus instensitas curah hujan untuk curah hujan jangka pendek. Rumus mononobe ini digunakan untuk menghitung intensitas curah hujan setiap waktu berdasarkan data curah hujan harian (Sosrodarsono, S, 2003).

2. Hidrograf Satuan Sintetik (HSS)

Hidrograf satuan adalah hidrograf limpasan langsung yang dihasilkan oleh hujan efektif merata didaerah aliran sungai (DAS) dengan intensitas tetap (diambil $1 \mathrm{~mm} / \mathrm{jam}$ ) dalam satu satuan waktu yang ditetapkan (diambil 1 jam) (Limantara, 2010). Cara hidrograf satuan telah pernah diakui oleh seluruh dunia sebagai cara yang paling dipercaya dan berguna dalam teknik peramalan debit banjir. Cara ini dapat diterapkan pada daerah-daerah pengaliran yang kurang dari $25 \mathrm{~km}^{2}$ sampai daerah pengaliran sebesar 5.000 $\mathrm{km}^{2}$ (Sosrodarsono, S, 2003).

\section{c. Analisis Hidrolika Kapasitas Penampang Sungai}

1. Pengukuran Debit

Pengukuran debit dapat dilakukan dengan 3 (tiga) metode yaitu metode Apung, metode Manning dan metode Current Meter (Sungai et al., 2018). Pengukuran debit dikatakan secara tidak langsung apabila kecepatan alirannya tidak diukur langsung, akan tetapi dihitung berdasarkan rumus hidraulis debit dengan rumus Manning, Chezy, serta Darcy Weisbach. Rumus Manning berlaku untuk kondisi Aliran Steady dan Aliran Uniform.

2. Perhitungan Debit Sungai Metode Mid Section

Dalam perhitungan kapasitas penampang sungai diperlukan data berupa dimensi saluran yang terdiri dari lebar dasar sungai, kedalaman air sungai serta kemiringan talud. Cara "mid section" dianggap bahwa kecepatan di setiap vertikal merupakan kecepatan rerata dari pias selebar setengah jarak antar pias di sebelah kiri dan kanannya. Debit di suatu pias adalah perkalian 
antara kecepatan rerata vertikal dan lebar tersebut. Di kedua tebing kiri dan kanan sungai kecepatan dianggap nol (Triatmodjo, 2008).

\section{Metode Penelitian}

Metode yang digunakan dalam penelitian ini adalah metode kuantitatif deskriftif. Metode ini disebut metode kuantitatif karena data penelitian berupa angka-angka dan analisis menggunakan statistic (Sugiyono, 2012). Selain data yang berupa angka, dalam penelitan kuantitatif juga ada data berupa informasi kualitatif (Arikunto, 2010).

Dalam penulisan penelitian ini dimulai dengan survei lapangan untuk melihat kondisi di lokasi studi dengan melakukan pengamatan langsung pada lokasi rencana penelitian serta mendatangi kantor/instansi terkait yang membidangi pengelolaan sungai pada wilayah tersebut, kemudian dilakukan identifikasi terhadap masalah-masalah tersebut dirumuskan, dilakukan studi pustaka sebagai landasan dasar untuk melakukan tindakan selanjutnya, kemudian dilakukan analisa. Untuk lebih jelasnya dapat dilihat pada Gambar 2 Bagan Alir Penelitian (flow chart).
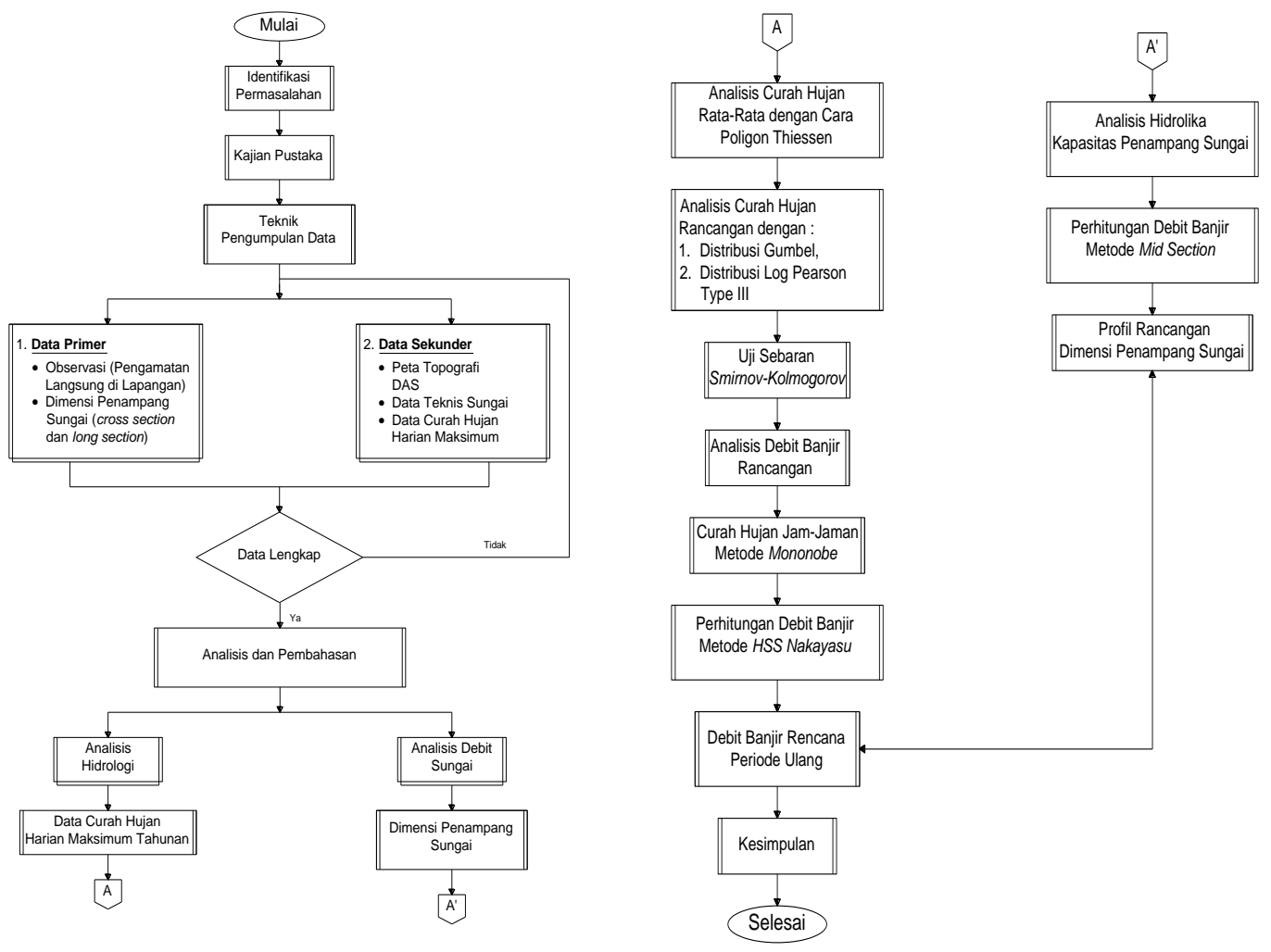

Gambar 2 Bagan Alir Penelitian (flow chart) 
Dalam penelitian ini berdasarkan sumbernya, data penelitian dikelompokan dalam 2 jenis, yaitu:

1. Data Primer

a. Dokumentasi kondisi lokasi kajian yang dalam hal ini Sungai Cijangkelok yang berada di Desa Cibingbin Kecamatan Cibingbin Kabupaten Kuningan.

b. Hasil pengukuran dimensi penampang sungai berupa cross section dan long section pada Sungai Cijangkelok yang diambil dari titik yang menwakili.

c. Informasi-informasi aktual lainnya terkait Sungai Cijangkelok yang didapat dari observasi lapangan dan informasi dari instansi terkait.

2. Data sekunder

a. Data Topografi

Berupa Peta Daerah Aliran Sungai Cisanggarung dan Peta Batas Wilayah Sungai Cijangkelok.

b. Data Teknis Sungai

Data ini berupa data Luas DAS, luas Catchment Area dan data pendukung lainnya.

c. Data Hidrologi

Data ini berupa data curah hujan harian maksimum yang digunakan dalam analisis ini bersumber dari periode pencatatan tahun 2005 sampai dengan tahun 2019 dipilih pos hujan yang berada di sekitar DAS Cijangkelok yaitu Sta. Ciwaru, Sta. Cibingbin dan Sta. Cibendung.

\section{Hasil dan Pembahasan}

\section{Analisis Hidrologi}

Dari metode perhitungan curah hujan wilayah yang ada digunakan metode Polygon Thiessen, karena kondisi topografi dan stasiun hujan tidak tersebar merata serta jumlah stasiun memenuhi syarat untuk digunakan metode ini yaitu minimal jumlah stasiun yang digunakan adalah 3 (tiga) pos stasiun pencatat hujan. Adapun jumlah stasiun yang masuk di daerah pengaliran sungai berjumlah 3 (tiga) buah stasiun yaitu Sta. Cibendung (A), Sta. Cibingbin (B), dan Sta. Ciwaru (C).

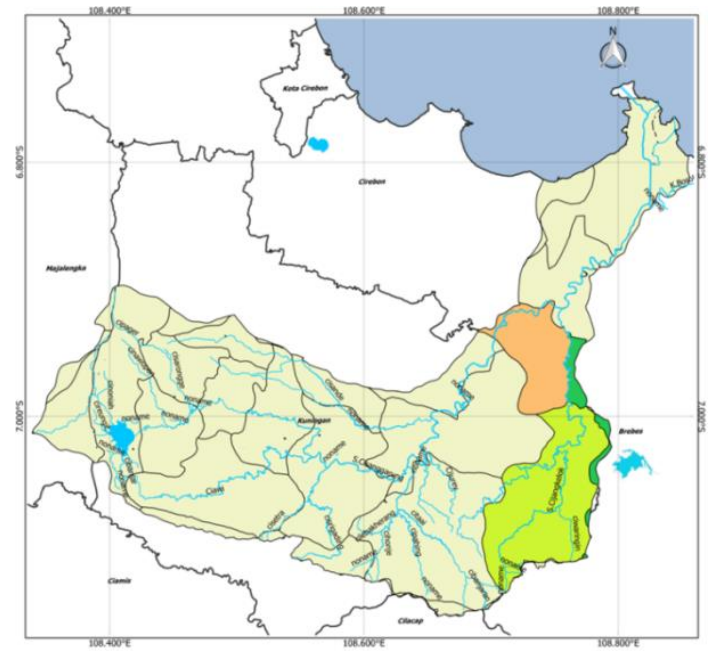




\section{Gambar 3 Peta Daerah Tangkapan Air Sungai Cijangkelok Sumber: Unit Hidrologi BBWS Cimanuk-Cisanggarung}

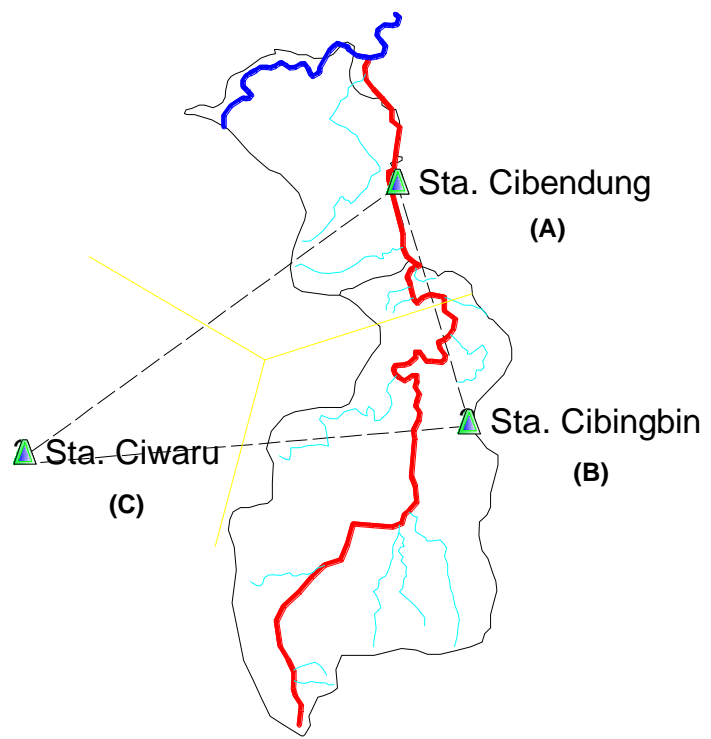

\section{Gambar 4 Luas Pengaruh Thiessen}

Dari tiga stasiun tersebut masing-masing dihubungkan untuk memperoleh luas daerah pengaruh dari tiap stasiun. Dimana masing-masing stasiun mempunyai daerah pengaruh yang dibentuk dengan garis-garis sumbu tegak lurus terhadap garis penghubung antara tiga stasiun. Luas DAS yang masuk kedalam poligon, merupakan luasan yang mewakili masing-masing stasiun hujan. Adapun perhitungan prosentase luas pengaruh tiap stasiun hujan disajikan dalam Tabel 1 sebagai berikut.

\section{Tabel 1}

\section{Luas Pengaruh Stasiun Hujan Terhadap DAS Sungai Cijangkelok}

\begin{tabular}{cccc}
\hline Stasiun & Luas $(\mathrm{Km} 2)$ & Bobot & Prosentase Luas $(\%)$ \\
\hline $\begin{array}{c}\text { Sta. } \\
\text { Cibendung }\end{array}$ & 56,2938 & 0,340 & 34,00 \\
\hline $\begin{array}{c}\text { Sta. } \\
\text { Cibingbin }\end{array}$ & 102,6534 & 0,620 & 62,00 \\
\hline Sta. Ciwaru & 6,6228 & 0,040 & 4,00 \\
\hline Jumlah & 165,57 & 1,00 & 100,00 \\
\hline
\end{tabular}

Sumber : Hasil Perhitungan, 2020

Hasil perhitungan curah hujan wilayah DAS dengan Poligon Thiessen didapatkan curah hujan maksimum tahunan kemudian dilakukan analisa frekuensi. Setelah diperoleh harga parameter satatistik dapat ditentukan metode/distribusi 
mana yang dapat dipakai dalam perhitungan debit banjir rancangann. Distribusi yang digunakan untuk analisis hujan rancangan yaitu Distribusi Gumbel dan Distribusi Log Pearson Type III. Hasil dari perhitungan kedua metode tersebut dipilih nilai yang memenuhi syarat parameter statistik yaitu hasil perhitungan metode Log Pearson Type III dan disajikan dalam Tabel 2 sebagai berikut.

Tabel 2

Syarat Parameter Statistik/Penggunaan Jenis Sebaran

\begin{tabular}{ccccc}
\hline No. & Distribusi & Persyaratan & $\begin{array}{c}\text { Hasil } \\
\text { Perhitungan }\end{array}$ & Keputusan \\
\hline 1. & Gumbel & $\mathrm{Cs}=1,14$ & $\mathrm{Cs}=1,47$ & Tidak \\
& & $\mathrm{Ck}=5,4$ & $\mathrm{Ck}=6,24$ & \\
\hline 2. & $\begin{array}{c}\text { Log Person Type } \\
\text { III }\end{array}$ & $\begin{array}{c}\text { Selain dari nilai } \\
\text { di atas }\end{array}$ & $\mathrm{Cs}=0,75$ & Ya \\
\hline
\end{tabular}

Sumber: Hasil Perhitungan, 2020

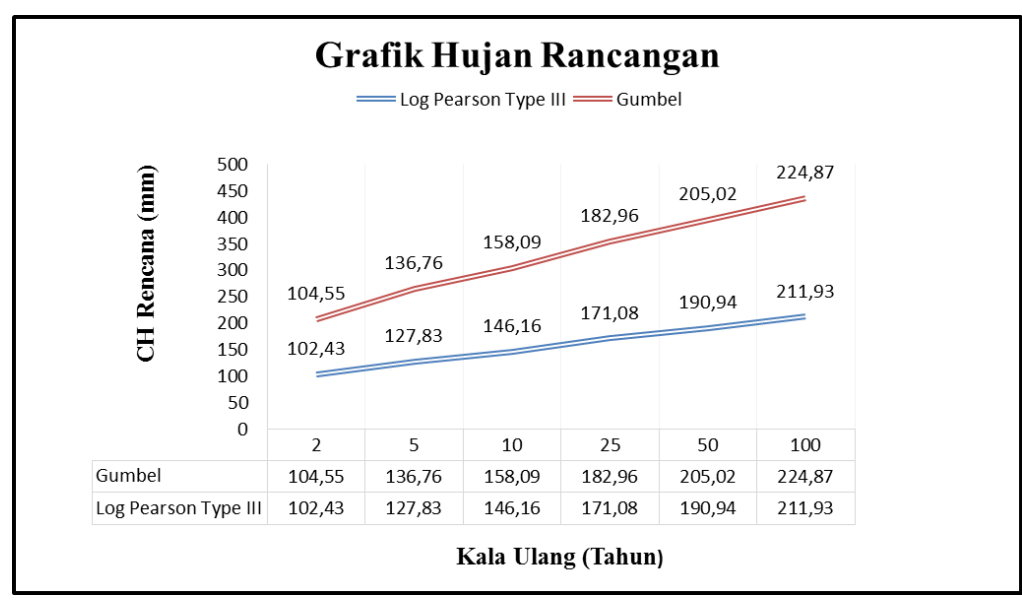

\section{Gambar 5}

Grafik Hujan Rancangan Distribusi Gumbel dan Distribusi Log Pearson Type III Berdasarkan Periode Ulang T Tahun

Uji Smirnov - Kolmogorov dilakukan untuk jenis Distribusi data Log Pearson Type III dengan asumsi :

a Tingkat Signifikasi $5 \%$.

b Hipotesa diterima apabila $\Delta_{\text {maks }}<\Delta_{c r}$.

c Hipotesa tidak dapat diterima jika $\Delta_{\text {maks }}>\Delta_{c r}$.

Dari hasil analisa frekuensi jenis distribusi yang memenuhi syarat yaitu distribusi Log Pearson Type III dengan nilai $C s=0,753$, selanjutnya dari hasil Uji keselarasan Smirnov-Kolmogorov dengan derajat signifikasi $5 \%$ dan nilai $\Delta_{\text {maks }}<$ $\Delta_{\mathrm{cr}}=0,134<0,338$., maka Metode Log Pearson Type III dapat digunakan untuk menghitung curah hujan periode ulang tertentu. 


\section{Perhitungan Distribusi Hujan Jam-Jaman}

Perhitungan distribusi hujan jam-jaman dilakukan dengan menggunakan metode Mononobe. Hubungan antara intensitas, lama hujan, dan frekuensi hujan dinyatakan dalam lengkung IDF (Intensity-Duration Frequency Curve). Analisis IDF disajikan dalam Gambar 6.

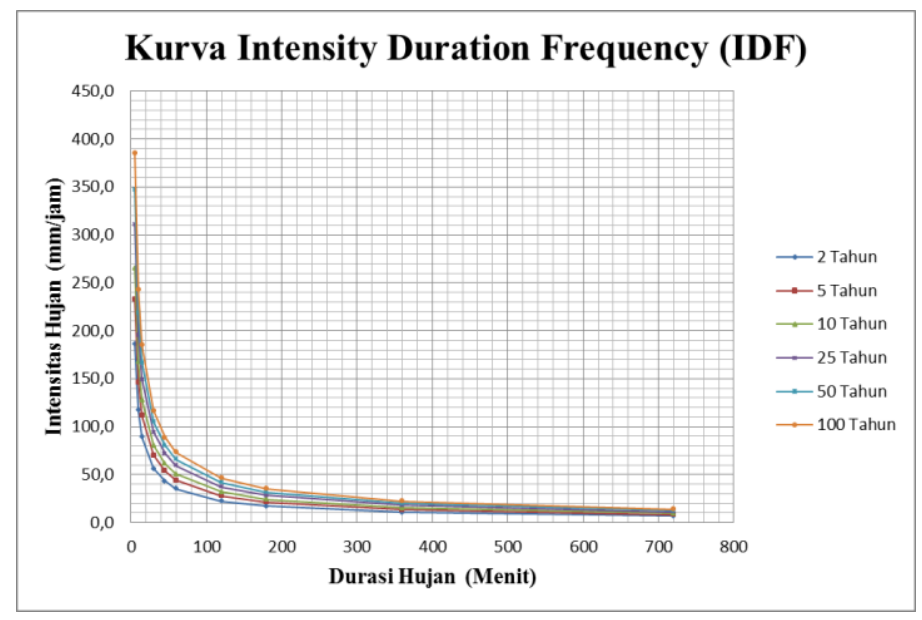

Gambar 6

\section{Grafik Intensitas Hujan}

Perhitungan untuk Intensitas Curah Hujan selama 4 Jam dengan kala ulang 2 Tahun dengan waktu konsentrasi diasumsikan selama 4 jam sebagai berikut :

a. Kala Ulang (2 Tahun) dengan Intensitas 4 Jam

$$
\begin{aligned}
& I=\left(\frac{R_{24}}{24}\right)\left(\frac{24}{t}\right)^{\frac{2}{3}} \\
& =\left(\frac{102,43}{24}\right)\left(\frac{24}{4}\right)^{\frac{-E}{3}} \\
& =14,092 \mathrm{~mm} / \mathrm{jam}
\end{aligned}
$$

\section{Hidrograf Satuan Sintetik (HSS) Nakayasu}

Dalam penyusunan penelitian ini, karena data debit tidak tersedia perhitungan debit banjir dihitung dengan metode empiris dengan parameter yang didapat bukan secara analitis tetapi berdasarkan korelasi antara hujan dan karakteristik DPS terhadap banjir, dalam hal ini metode empiris yang dipakai adalah Metode Hidrograf Satuan Sintetik (HSS) Nakayasu. Cara ini dapat diterapkan pada daerah-daerah pengaliran yang kurang dari $25 \mathrm{~km} 2$ sampai daerah pengaliran sebesar $5.000 \mathrm{~km} 2$ (Sosrodarsono, S, 2003) Perhitungan Hidrograf Satuan Sintetik Nakayasu dilakukan sebagai berikut:

a. Menghitung parameter-parameter yang diperlukan:

Luas Daerah Aliran Sungai (A) $\quad: 165,57 \mathrm{Km}^{2} \quad$ (Hasil dari Peta RBI)

Panjang Sungai (L) : : $36,61 \mathrm{Km} \quad$ (Hasil dari Peta RBI) 
Analisis Debit Banjir Sungai Cijangkelok di Desa Cibingbin Kecamatan Cibingbin Kabupaten Kuningan

$$
\begin{aligned}
\operatorname{tg} & =0,40+0,058 \times \mathrm{L} \quad(\mathrm{L} \geq 15 \mathrm{Km}) \\
& =0,40+0,058 \times 36,61 \\
& =2,523 \quad \mathrm{Jam} \\
& =1 / \operatorname{tg} \times 0,47+(\text { A.L })^{0,25} \\
& =1,643 \quad \mathrm{Jam} \\
\operatorname{tr} & =(0,5-1) \mathrm{tg} \\
& =2,52 \quad \mathrm{Jam} \\
\mathrm{Tp} & =\operatorname{tg}+0.80 \mathrm{tr} \\
& =4,542 \quad \mathrm{Jam} \\
\mathrm{T}_{0,3} & =\alpha \operatorname{tg} \quad \mathrm{Jam} \\
& =4,147 \quad \mathrm{~N} \quad \mathrm{~A} \cdot \mathrm{Ro} /\left[3,6\left(0,3 \mathrm{Tp}+\mathrm{T}_{0,3}\right)\right] \\
\mathrm{Qp} & =1 \times 165,57 \times 1 /[3,6(0,3 \times 4,542+4,147)] \\
& =8,347 \quad \mathrm{~m}^{3} / \mathrm{dt}
\end{aligned}
$$

b. Menghitung koordinat kurva naik dan kurva turun hidrograf :

1) Pada Kurva Naik (Rising Limb)

$0 \leq \mathrm{t}<\mathrm{Tp}$ berarti :

$0 \leq \mathrm{t}<4,542$

Rumus kurva naik :

$$
\text { Qn } \quad \begin{aligned}
& =\mathrm{Qp} \times(\mathrm{t} / \mathrm{Tp})^{2,4} \\
& =8,347 \times(\mathrm{t} / 4,542)^{2,4} \\
& =0,221
\end{aligned}
$$

2) Pada Kurva Turun (Recesion Line)

- $\quad\left(\mathrm{Tp}+\mathrm{T}_{0,3}\right)$

- $\mathrm{Tp} \leq \mathrm{t}<\left(\mathrm{Tp}+\mathrm{T}_{0,3}\right) \quad$ berarti : $\quad 4,542 \leq \mathrm{t}<8,689$

$\mathrm{Qt}_{1}=\mathrm{Qp} \times 0,3^{\wedge}[(\mathrm{t}-\mathrm{Tp}) / \mathrm{T} 0,3]$

- $\mathrm{Qt}_{1}=8,347 \times 0,3^{\wedge}[(\mathrm{t}-4,542) / 4,147]$

- $\mathrm{Qt}_{1}=2,504$

- $\quad\left(\mathrm{Tp}+\mathrm{T}_{0,3}\right) \leq \mathrm{t}<\left(\mathrm{Tp}+\mathrm{T}_{0,3}+1,5 \mathrm{~T}_{0,3}\right) \quad$ berarti : $\quad 4,542 \leq \mathrm{t}<14,910$

$$
\begin{aligned}
& \mathrm{Qt}_{2}=\mathrm{Qp} \times 0,3^{\wedge}\left[\left(\mathrm{t}-\mathrm{Tp}+0,5 \mathrm{~T}_{0,3}\right) /\left(1,5 \mathrm{~T}_{0,3}\right]\right. \\
& \mathrm{Qt}_{2}=8,347 \times 0,3^{\wedge}[(\mathrm{t}-4,542+0,5 \times 4,147) /(1,5 \times 4,147] \\
& \mathrm{Qt}_{2}=0,751
\end{aligned}
$$




$$
\begin{aligned}
-\mathrm{t} \geq(\mathrm{Tp} & \left.+\mathrm{T}_{0,3}+1,5 \mathrm{~T}_{0,3}\right) \quad \text { berarti }: \quad \mathrm{t} \geq 14,910 \\
\mathrm{Qt}_{3} & =\mathrm{Qp} \times 0,3^{\wedge}\left[\left(\mathrm{t}-\mathrm{Tp}+1,5 \mathrm{~T}_{0,3}\right) /\left(2 \mathrm{~T}_{0,3}\right)\right] \\
\mathrm{Qt}_{3} & =8,347 \times 0,3^{\wedge}[(\mathrm{t}-4,542+1,5 \times 4,147) /(2 \times 4,147] \\
\mathrm{Qt}_{3} & =0,2008
\end{aligned}
$$

\begin{tabular}{|c|c|c|c|c|c|c|}
\hline \multirow{2}{*}{$\begin{array}{c}\text { Waktu } \\
\text { Jam }\end{array}$} & \multicolumn{6}{|c|}{ Kata Ulang } \\
\hline & 2 & 5 & 10 & 25 & 50 & 100 \\
\hline 0 & 0,000 & 0,000 & 0,000 & 0,000 & 0,000 & 0,000 \\
\hline 1 & 7,843 & 9,788 & 11,192 & 13,100 & 14,620 & 16,228 \\
\hline 2 & 46,336 & 57,828 & 66,120 & 77,395 & 86,377 & 95,875 \\
\hline 3 & 139,387 & 173,957 & 198,900 & 232,819 & 259,838 & 288,409 \\
\hline 4 & 310,505 & 387,513 & 443,077 & 518,636 & 578,825 & 642,471 \\
\hline 4,542 & 503,136 & 627,919 & 717,954 & 840,388 & 937,916 & 1041,047 \\
\hline 5 & 594,745 & 742,248 & 848,677 & 993,404 & 1108,690 & 1230,598 \\
\hline 6 & 586,808 & 732,342 & 837,351 & 980,146 & 1093,893 & 1214,175 \\
\hline 7 & 509,886 & 636,344 & 727,587 & 851,664 & 950,501 & 1055,015 \\
\hline 8 & 396,405 & 494,718 & 565,654 & 662,116 & 738,955 & 820,209 \\
\hline 8,689 & 304,194 & 379,637 & 434,073 & 508,096 & 567,061 & 629,413 \\
\hline 9 & 249,593 & 311,495 & 356,159 & 416,896 & 465,277 & 516,438 \\
\hline 10 & 207,599 & 259,086 & 296,236 & 346,754 & 386,995 & 429,548 \\
\hline 11 & 175,864 & 219,480 & 250,951 & 293,746 & 327,835 & 363,883 \\
\hline 12 & 149,067 & 186,037 & 212,713 & 248,987 & 277,882 & 308,437 \\
\hline 13 & 122,836 & 153,301 & 175,282 & 205,173 & 228,984 & 254,162 \\
\hline 14 & 101,221 & 126,325 & 144,438 & 169,069 & 188,690 & 209,438 \\
\hline 14,910 & 83,871 & 104,672 & 119,681 & 140,090 & 156,348 & 173,539 \\
\hline 15 & 73,751 & 92,041 & 105,239 & 123,186 & 137,481 & 152,599 \\
\hline 16 & 64,809 & 80,882 & 92,480 & 108,251 & 120,813 & 134,097 \\
\hline 17 & 57,286 & 71,493 & 81,745 & 95,685 & 106,789 & 118,531 \\
\hline 18 & 50,838 & 63,447 & 72,544 & 84,915 & 94,770 & 105,191 \\
\hline 19 & 43,969 & 54,874 & 62,742 & 73,442 & 81,965 & 90,978 \\
\hline 20 & 38,028 & 47,460 & 54,265 & 63,519 & 70,890 & 78,685 \\
\hline 21 & 32,890 & 41,047 & 46,933 & 54,937 & 61,312 & 68,054 \\
\hline 22 & 28,446 & 35,501 & 40,592 & 47,514 & 53,028 & 58,859 \\
\hline 23 & 24,603 & 30,704 & 35,107 & 41,094 & 45,863 & 50,906 \\
\hline 24 & 21,279 & 26,556 & 30,364 & 35,542 & 39,666 & 44,028 \\
\hline
\end{tabular}

Tabel 3

Rekap Perhitungan Hidrograf Banjir Rancangan Metode HSS Nakayasu

Sumber: Hasil Perhitungan, 2020 


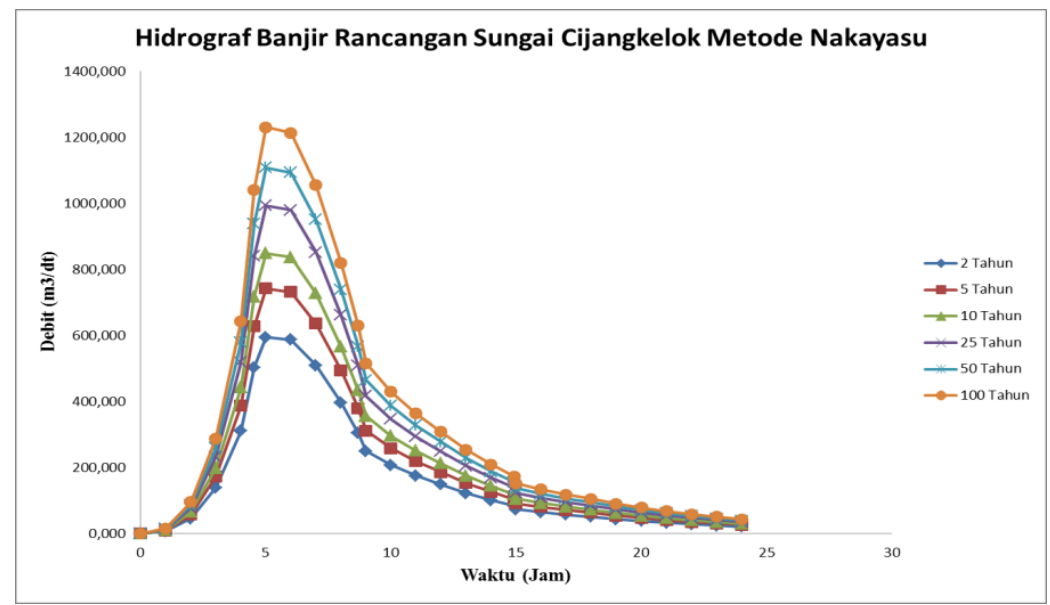

\section{Gambar 7}

Grafik Hujan Rancangan Nakayasu Berdasarkan Periode Ulang T Tahun

\section{Perhitungan Debit Metode Mid Section}

Hasil perhitungan berdasarkan pada data ukur penampang sebagai berikut.

Dengan :

Lebar Dasar Sungai $(B)=25,7 \mathrm{~m}$

Tinggi Penampang (h) $\quad=3 \mathrm{~m}$

$\mathrm{m} \quad=2$

Kemiringan Alur Sungai (i) $=0,0077$

Koef. Kekasaran Manning (n) = 0,030

(diambil 0,030 karena merupakan saluran terbuka dengan dasar saluran pasir dan kerikil).

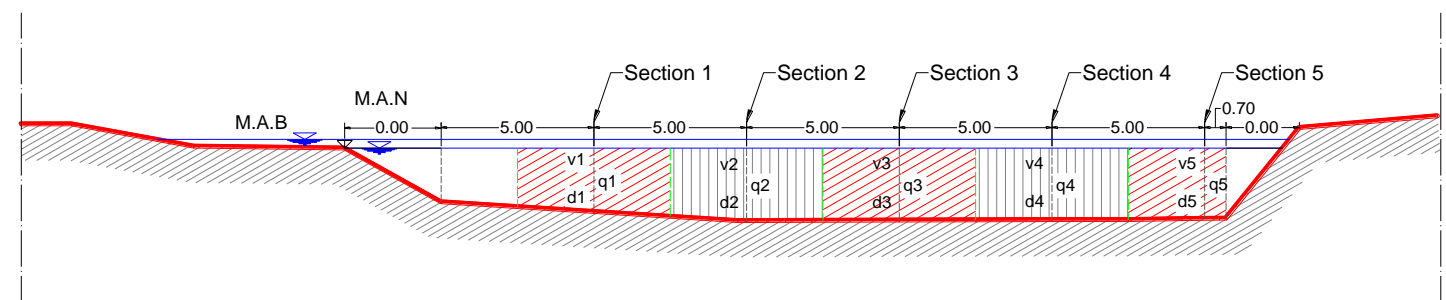

Gambar 8

Potongan Melintang Metode Mid Section

Dengan kapasitas sungai yang didapat dari hasil perhitungan debit menggunakan metode mid section $239,30 \mathrm{~m}^{3} / \mathrm{dt}$ dan hasil perhitungan Hidrograf Satuan Sintetik Nakayasu sebesar 742,248 $\mathrm{m}^{3} /$ detik yang terjadi pada Q rencana kala ulang selama 5 Tahun. Maka dapat disimpulkan bahwa Sungai Cijangkelok sudah tidak dapat menampung dan berpotensi banjir, dan perlu adanya normalisasi atau peninggian bangunan air dan atau tanggul pada Sungai Cijangkelok. Adapun Hasil perhitungan metode mid section disajikan dalam Tabel 4. 
Tabel 4

Perhitungan Metode Mid Section

\begin{tabular}{|c|c|c|c|c|c|c|c|c|}
\hline \multirow{2}{*}{\multicolumn{2}{|c|}{$\begin{array}{c}\text { Section } \\
\mathbf{a}\end{array}$}} & \multirow{2}{*}{$\begin{array}{c}\begin{array}{c}\text { Distance } \\
\text { LB (m) }\end{array} \\
\text { b }\end{array}$} & \multicolumn{2}{|c|}{$\begin{array}{c}\text { Kedalam } \\
\text { Air di (m) }\end{array}$} & \multirow{2}{*}{$\begin{array}{c}\text { Mean } \\
\mathbf{v} \\
\mathbf{d}\end{array}$} & \multirow{2}{*}{$\begin{array}{c}\text { b panel } \\
(\mathbf{m})\end{array}$} & \multicolumn{2}{|l|}{$\begin{array}{l}\text { b mids } \\
(\mathbf{m})\end{array}$} \\
\hline & & & & c & & & $\mathbf{F}$ & \\
\hline LB & & 0 & & 0,88 & & 5 & & \\
\hline I & Section 1 & 5 & $\mathrm{~d} 1$ & 2,09 & 4,30 & 5 & 5 & 44,93 \\
\hline II & Section 2 & 10 & $\mathrm{~d} 2$ & 2,39 & 4,65 & 5 & 5 & 55,52 \\
\hline III & Section 3 & 15 & $\mathrm{~d} 3$ & 2,37 & 4,62 & 5 & 5 & 54,79 \\
\hline IV & Section 4 & 20 & $\mathrm{~d} 4$ & 2,35 & 4,60 & 5 & 5 & 54,06 \\
\hline $\mathrm{V}$ & Section 5 & 25 & d5 & 2,31 & 4,56 & 0,7 & 2,85 & 29,99 \\
\hline $\mathrm{RB}$ & & 25,7 & & 1,15 & & & & \\
\hline
\end{tabular}

\section{Perhitungan Dimensi Rencana Penampang Sungai Yang Ideal}

Perhitungan dimensi rencana penampang sungai dilakukan dengan menghitung luas penampang basah (A), keliling basah (P) dan kecepatan pengaliran (v) menggunakan rumus stickler serta mencari tinggi h menggunakan cara Trial and Erorr (coba-coba) dengan asumsi:

Lebar Dasar Sungai (B) $=25 \mathrm{~m}$

Kemiringan Talud (t) $\quad=1: 2=\mathrm{m}=2$

Elev. Dasar di Hulu (A') $=90 \mathrm{~m}$

Elev. Dasar di Hilir (B') $=86 \mathrm{~m}$

Koef. Kekasaran Dinding $=45$

Kemiringan Dasar Sungai $(I)=0,008$

\begin{tabular}{|c|c|c|c|c|c|}
\hline Kedalaman Air (h) & Luas Penampang Basah (A) & Keliling Basah (P) & Radius Hidrolik (R) & Kecepatan Aliran $(\mathbf{V})$ & Debit (Q) \\
\hline 1 & $2=(\mathrm{b}+\mathrm{mh}) \mathrm{h}$ & $3=b+2 h \sqrt{1+m^{2}}$ & $4=2 / 3 ; \mathrm{A} / \mathrm{P}$ & $5=\mathrm{k} \cdot R^{\frac{2}{3}} \times I^{\frac{1}{2}}$ & $6=2 \times 5 ; \mathrm{AxV}$ \\
\hline 1,00 & 27 & 29,472 & 0,916 & 3,797 & $102,5076<742,248$ \\
\hline 1,50 & 42 & 31,708 & 1,325 & 4,854 & $203,8881<742,248$ \\
\hline 2,00 & 58 & 33,944 & 1,709 & 5,753 & $333,6516<742,248$ \\
\hline 2,50 & 75 & 36,180 & 2,073 & 6,544 & $490,7698<742,248$ \\
\hline 3,00 & 93 & 38,416 & 2,421 & 7,257 & $674,8666<742,248$ \\
\hline 3,50 & 112 & 40,652 & 2,755 & 7,910 & $885,9235>742,248$ \\
\hline 3,40 & 108,12 & 40,205 & 2,689 & 7,783 & $841,5481>742,248$ \\
\hline $\mathbf{3 , 2 0}$ & $\mathbf{1 0 0 , 4 8}$ & $\mathbf{3 9 , 3 1 1}$ & $\mathbf{2 , 5 5 6}$ & $\mathbf{7 , 5 2 4}$ & $\mathbf{7 5 6 , 0 4 6 8}>\mathbf{7 4 2 , 2 4 8}$ \\
\hline
\end{tabular}

\section{Gambar 9}

\section{Perhitungan Tinggi Muka Air (h) dengan Cara Trial and Error}

Berdasarkan hasil perhitungan tabel diatas debit rencana kala ulang 5 tahun $742,248 \mathrm{~m}^{3} / \mathrm{dt}$ didapat tinggi $\mathrm{h}$ dengan cara coba-coba pada kedalaman 3,20 m. Penentuan periode ulang didasarkan pada besarnya debit banjir maksimum yang telah ditentukan berdasarkan kala ulang, faktor keamanan, ekonomi, dan sosial di lokasi kajian penelitian dalam hal ini di Desa Cibingbin Kecamatan Cibingbin 
Kabupaten Kuningan. Adapun Profil Rancangan dimensi yang ideal dari sungai Cijangkelok disajikan pada Gambar 10.

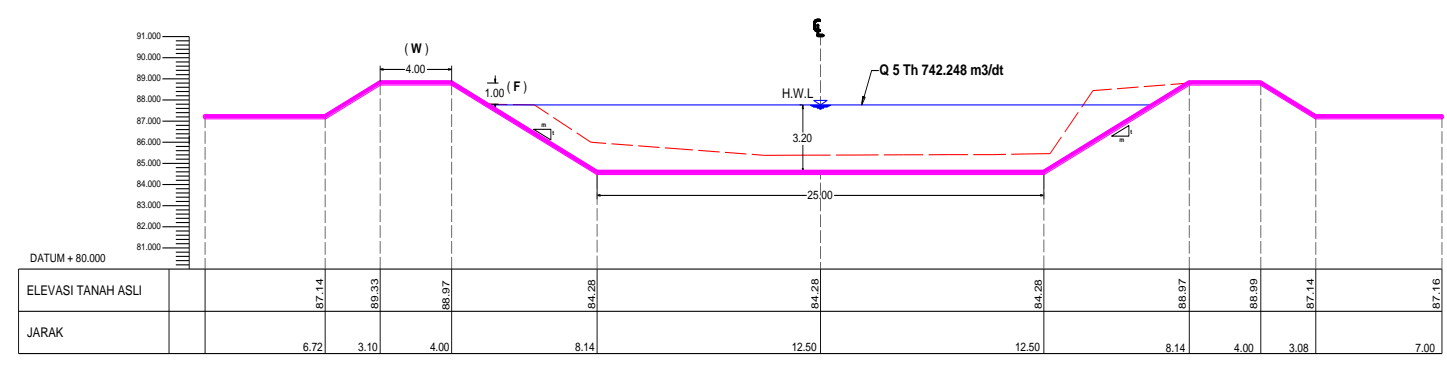

Gambar 10

Rencana Profil Rancangan Dimensi Sungai Cijangkelok

Dalam merencanakan dimensi penampang Sungai Cijangkelok, berdasar pada data debit maksimum dengan debit rencana kala ulang 5 Tahun sebesar 742,248 $\mathrm{m}^{3} /$ detik maka asumsikan dengan cara normalisasi alur sungai pada penampang Sungai Cijangkelok.

Data Desain:

$\mathrm{Q}$ normal desain $=239,30 \mathrm{~m}^{3} /$ detik

$\mathrm{Q}$ banjir desain $\quad=742,248 \mathrm{~m}^{3} /$ detik (Kala Ulang $5 \mathrm{Th}$ )

Kemiringan Dasar Sungai $(I)=0,008$

Lebar Dasar Sungai $(B)=25 \mathrm{~m}$

Kemiringan Talud (t) $=1: 2$

$\mathrm{m} \quad=2$

Tinggi Jagaan $(\mathrm{F}) \quad=1 \mathrm{~m}$

(dari tabel Hubungan antara Debit Banjir Rencana dengan Tinggi Jagaan)

Lebar Tanggul $(\mathrm{W}) \quad=4 \mathrm{~m}$

(dari tabel Debit Banjir Rencana dengan Lebar Puncak Tanggul)

Dengan dimensi penampang tersebut, Sungai Cijangkelok dapat menampung debit banjir rencana dengan Kala Ulang 5 Tahun sebesar 742,248 m³/detik.

\section{Kesimpulan}

Perhitungan analisis hidrologi didapatkan curah hujan rancangan sebesar 127,83 mm kala ulang 5 Tahun dengan menggunakan metode Log Pearson Type III. Setelah curah hujan rancangan didapat, maka diperoleh debit banjir rancangan sebesar 742,248 $\mathrm{m}^{3} / \mathrm{dt}$ kala ulang 5 tahun dengan menggunakan metode Hidrograf Satuan Sintetik (HSS) Nakayasu.

Untuk mengurangi resiko terjadinya kerusakan DAS dibutuhkan suatu upaya pengendalian banjir berupa analisis debit banjir. Debit banjir rencana adalah debit maksimum dari suatu sungai, atau saluran yang besarnya didasarkan kala ulang 
tertentu. Analisis debit rencana sangat penting sebagai langkah awal dalam upaya penanggulangan banjir.

Metode penelitian yang digunakan dalam penelitian ini adalah metode kuantitatif deskriftif. Penelitian kuantitatif sesuai dengan namanya banyak dituntut menggunakan angka, mulai dari pengumpulan data, penafsiran terhadap data tersebut, serta penampilan dan hasilnya. Demikian juga pemahaman akan kesimpulan penelitian disertai tabel, grafik, bagan, gambar atau tampilan lain. Selain data yang berupa angka, dalam penelitan kuantitatif juga ada data berupa informasi kualitatif.

Pengurangan kapasitas aliran banjir pada sungai dapat disebabkan oleh pengendapan berasal dari erosi DAS dan erosi tanggul sungai yang berlebihan dan sedimentasi di sungai itu karena tidak adanya vegetasi penutup dan adanya penggunaan lahan yang tidak tepat.

Pada lokasi penelitian bencana banjir tersebut sangat dipengaruhi oleh faktor alam berupa curah hujan dengan intensitas lama disamping itu faktor ulah manusia juga berperan penting seperti penggunaan lahan yang tidak tepat (pemukiman di daerah bantaran sungai, di daerah resapan, penggundulan hutan, dan sebagainya), pembuangan sampah ke dalam sungai, pembangunan pemukiman di daerah dataran banjir dan sebagainya.

Debit existing pada penampang sungai di lokasi penelitian yang dapat mewakili didapat 239,30 $\mathrm{m}^{3} / \mathrm{dt}$ menggunakan metode mid section dan 742,248 $\mathrm{m}^{3} /$ detik hasil perhitungan Hidrograf Satuan Sintetik (HSS) Nakayasu terjadi pada kala ulang 5 Tahun sehingga dapat disimpulkan bahwa kondisi saat ini Sungai Cijangkelok sudah tidak dapat menampung debit banjir rencana kala ulang 5 tahun.

\section{BIBLIOGRAFI}

Arikunto, Suharsimi. (2010). Prosedur Penelitian Suatu Pendekatan Praktik. 2010. Jakarta: Rineka Cipta.

Kodoatie, R. J. dkk. (2021). Tata Ruang Sungai Aluvial dan Sungai Non-Aluvial CAT dan Non-CAT. Google Scholar

Lalu Budi, Arianto. (2020). Evaluasi Saluran Drainase Terowongan Jalur Bypass Bandara Internasional Lombok Untuk Mengatasi Genangan Air. Universitas Muhammadiyah Mataram. Google Scholar

Limantara, Ir Lily Montarcih. (2010). Rekayasa Hidrologi: Edisi Revisi. Penerbit Andi. Google Scholar

Manurung, Yanto Horas Mangihut. (2017). Tinjauan Kritis terhadap Peraturan Menteri PUPR Nomor 01/PRT/M/2015. Prosiding Seminar Heritage IPLBI, 100, 103. Google Scholar

Neno, Abdul Kamal, Harijanto, Herman, \& Wahid, Abdul. (2016). Hubungan debit air dan tinggi muka air di sungai lambagu kecamatan tawaeli kota palu. Jurnal Warta 
Analisis Debit Banjir Sungai Cijangkelok di Desa Cibingbin Kecamatan Cibingbin Kabupaten Kuningan

Rimba, 4(2). Google Scholar

Oktarian, Deni. (2016). Analisis Spasial Perubahan Penggunaan Lahan Di DAS Babon Hulu Terhadap Debit Puncak Sungai Babon Jawa Tengah. Universitas Negeri Semarang. Google Scholar

Sosrodarsono, S, Kensaku Takeda. (2003). Hidrologi Untuk Pengairan. Cetakan Kesembilan. Google Scholar

Sugiyono, P. D. (2012). Metode Penelitian Kuantitatif Kualitatif Dan R\&D (Vol. 8). Alfabeta. Bandung. Google Scholar

Sungai, Pengelolaan Daerah Airan, Mengajar, Dan Aplikasinya Dalam Proses Belajar, Pertama, Edisi, Naharuddin, M. Si, Harijanto, Ir Herman, \& Wahid, M. P. Dr Ir Abdul. (2018). Buku Ajar. Google Scholar

Suripin. (2019). Mekanika Fluida dan Hidraulika Saluran Terbuka untuk Teknik Sipil.

Triatmodjo, Bambang. (2008). Hidrologi Terapan, Beta Offset. Yogyakarta. Google Scholar

Triwibowo, Soesetyo. (2021). Analisa Debit Banjir Rancangan Di Daerah Aliran Sungai Popalo. Prosiding SENTRA (Seminar Teknologi Dan Rekayasa), (6), 57-69. Google Scholar

\section{Copyright holder: \\ Nono Carsono (2021)}

First publication right:

Journal Syntax Literate

This article is licensed under:

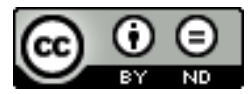

